
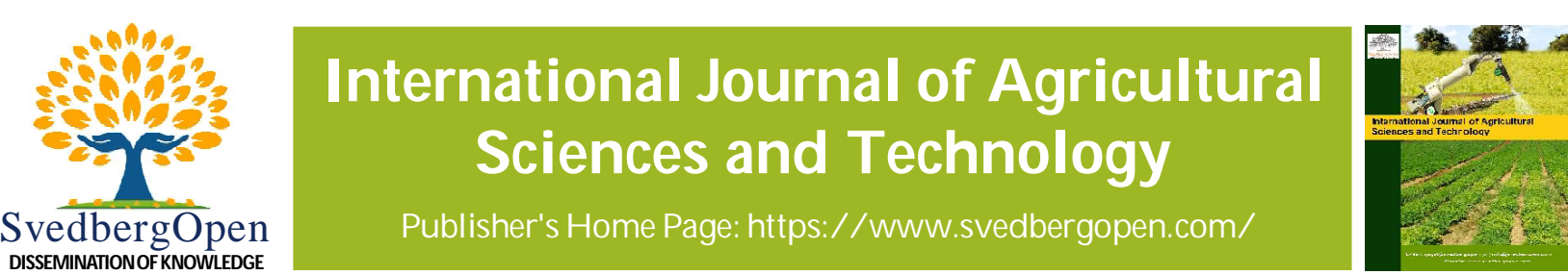

\title{
Thermal Inactivation of Salmonella spp. Within Refrigerated or Frozen Turkey Burgers Following Pan Frying
}

Minh Duong ${ }^{1}$, Anna, C.S. Porto-Fett ${ }^{2}$, Bradley A Shoyer ${ }^{3}$, Yangjin Jung ${ }^{4}$, Laura, E. Shane ${ }^{5}$, Manuela Osoria ${ }^{6}$, Elizabeth Henry ${ }^{7}$, Benjamin, J. Chapman ${ }^{8}$ and John, B. Luchansky ${ }^{9 *}$

\begin{abstract}
'Department of Food Science, North Carolina State University, Raleigh, NC, 27606, USA. E-mail: minhd16@vt.edu and bjchapma@ncsu.edu ${ }^{2}$ United States Department of Agriculture, Agricultural Research Service, Eastern Regional Research Center, 600 East Mermaid Lane, Wyndmoor, PA 19038, USA. E-mail: anna.portofett@usda.gov

${ }^{3}$ United States Department of Agriculture, Agricultural Research Service, Eastern Regional Research Center, 600 East Mermaid Lane, Wyndmoor, PA 19038, USA. E-mail: brad.shoyer@usda.gov

${ }^{4}$ United States Department of Agriculture, Agricultural Research Service, Eastern Regional Research Center, 600 East Mermaid Lane, Wyndmoor, PA 19038, USA. E-mail: fsyj0502@gmail.com

${ }^{5}$ United States Department of Agriculture, Agricultural Research Service, Eastern Regional Research Center, 600 East Mermaid Lane, Wyndmoor, PA 19038, USA. E-mail: laura.shane@usda.gov

${ }^{6}$ United States Department of Agriculture, Agricultural Research Service, Eastern Regional Research Center, 600 East Mermaid Lane, Wyndmoor, PA 19038, USA. E-mail: manuela.osoria@usda.gov

${ }^{7}$ United States Department of Agriculture, Agricultural Research Service, Eastern Regional Research Center, 600 East Mermaid Lane, Wyndmoor, PA 19038, USA. E-mail: elhenry312@gmail.com

${ }^{8}$ Department of Food Science, North Carolina State University, Raleigh, NC, 27606, USA. E-mail: minhd16@vt.edu and bjchapma@ncsu.edu ${ }^{9}$ United States Department of Agriculture, Agricultural Research Service, Eastern Regional Research Center, 600 East Mermaid Lane, Wyndmoor, PA 19038, USA. E-mail: john.luchansky@usda.gov
\end{abstract}

\section{Article Info}

Volume 1, Issue 4, November 2021

Received : 23 April 2021

Accepted : 16 September 2021

Published : 05 November 2021

doi: 10.51483/IJAGST.1.4.2021.1-12

\begin{abstract}
Turkey burgers (ca. 1.25 or $2.5 \mathrm{~cm}$ thick) were inoculated (ca. $6.5 \log$ CFU/g) with a Salmonella spp. cocktail, stored at $4{ }^{\circ} \mathrm{C}(18 \mathrm{~h})$ or $-20^{\circ} \mathrm{C}(30 \mathrm{~d})$, and then cooked in 15 or $30 \mathrm{~mL}$ of canola oil. Regardless of oil volume, cooking refrigerated $1.25 \mathrm{~cm}$ thick burgers to $57.2,65.6,73.9$, or $82.2^{\circ} \mathrm{C}$ delivered reductions of ca. 4.8 to $\geq 6.0 \mathrm{log} \mathrm{CFU} / \mathrm{g}$ compared to ca. 3.0 to $\geq 5.0 \mathrm{log}$ $\mathrm{CFU} / \mathrm{g}$ for frozen burgers. Cooking refrigerated $2.5 \mathrm{~cm}$ thick burgers to 57.2 to $82.2{ }^{\circ} \mathrm{C}$ delivered reductions of ca. 2.8 to $\geq 6.1 \log$ CFU/g compared to ca. 2.4 to $\geq 5.1 \log$ CFU/g for frozen burgers. Average internal temperatures for refrigerated or frozen burgers cooked to $57.2,65.6,73.9$, or $82.2^{\circ} \mathrm{C}$ ranged from 38.3 to $96.2,48.0$ to $99.4,55.2$ to 98.5 , or 59.4 to $98.3{ }^{\circ} \mathrm{C}$, respectively. Thus, pan frying refrigerated or frozen Turkey burgers to $\geq 73.9{ }^{\circ} \mathrm{C}$ delivered a $\geq 5.0-\log$ reduction of Salmonella.

Keywords: Salmonella, Ground turkey, Thermal inactivation, Cooking, Turkey burgers, Pan frying

(C) 2021 Minh Duong et al. This is an open access article under the CC BY license (https://creativecommons.org/licenses/by/4.0/), which permits unrestricted use, distribution, and reproduction in any medium, provided you give appropriate credit to the original author(s) and the source, provide a link to the Creative Commons license, and indicate if changes were made.
\end{abstract}

\section{Introduction}

Demand for poultry continues to increase worldwide (ca. $14 \mathrm{~kg} /$ person annually), including within the US wherein consumption was recently estimated at ca. $50 \mathrm{~kg} /$ person annually (OECD, 2017). As reported by Rouger et al. (2017),

* Corresponding author: John, B. Luchansky, United States Department of Agriculture, Agricultural Research Service, Eastern Regional Research Center, 600 East Mermaid Lane, Wyndmoor, PA 19038, USA. 
turkey products comprise ca. $25 \%$ of poultry meat consumed worldwide, being a distant second to chicken products which were estimated at ca. $75 \%$ of total poultry meat consumed. Poultry was also among the most common vehicles of foodborne illness reported in the US between 1998 and 2012, largely attributed to, as expected, Campylobacter and Salmonella (Chai et al., 2017). In fact, active surveillance by the US Centers for Disease Control and Prevention (CDC) identified 11 outbreaks of salmonellosis over the past decade from consumption of undercooked chicken or turkey, inclusive of intact, non-intact, and comminuted products (CDC, 2021a). In addition to causing salmonellosis, another consequence of its pervasiveness in raw (ground) turkey has been several, and at times expansive, recalls of turkey products due to contamination with Salmonella spp. Pertinent to the present study, a notable outbreak attributed to Salmonella Hadar occurred in 2011 across 10 states which resulted in 12 persons being infected and ca. 55,000 lbs of frozen, raw turkey burger products being recalled (CDC, 2011a). A second outbreak, attributed to Salmonella Heidelberg, also occurred in 2011, this one being distributed across 34 states and leading to 136 persons becoming infected, including one death, and ca. 36.2 million lbs of raw ground turkey products being recalled (CDC, 2011b). Another outbreak (Hassan et al., 2019; USDA, 2018) which occurred between 2018-2019 involving Salmonella Reading across 42 states and the District of Columbia (DC), was linked to raw turkey products such as whole turkey, turkey pieces and ground turkey, and raw turkey pet food, as well as live turkeys handled by workers in a processing facility; there were 356 cases which resulted in 132 hospitalizations and one death, and ca. 40,000 lbs of raw pet food and ca. 300,000 lbs of raw ground turkey were recalled. Also in 2018-2019, a multistate outbreak associated with Salmonella Schwarzengrund resulted in seven cases of salmonellosis and one hospitalization across three states, as well as a nationwide recall of ca. $78,000 \mathrm{lbs}$ of fresh raw ground turkey products (CDC, 2019 and USDA, 2019). Lastly, a multistate outbreak is currently under investigation due to the occurrence of 28 illnesses and 2 hospitalizations attributed to raw ground turkey contaminated with Salmonella Hadar (CDC, 2021b): no recall was issued since contaminated products are no longer available for purchase (USDA, 2021). However, a public health alert was issued for ca. 212,000 lbs of the associated raw ground turkey products, given that consumers may still have the (potentially) contaminated ground turkey stored frozen at home (USDA, 2021). Investigations of poultry-linked outbreaks identified food handling errors and inadequate cooking as the most common factors leading to poultry associated salmonellosis (Chai et al., 2017).

It is widely known that raw turkey products harbor Salmonella. For example, cells of Salmonella were recovered from ca. $50 \%$ of 296 raw ground turkey samples from some 40 Federally-inspected processing plants nationwide (USDA, 1996). As another example (Cui et al., 2015), over a 10-month period at a cooperating turkey abattoir a total of 300 samples/sets of matched turkey parts (i.e., neck skin, spleen, and drumsticks) from the same bird from among 20 flocks were analyzed. From among each of the 300 separate but matched turkey parts tested, cells of Salmonella were recovered from $42 \%$ of neck skin, $9.3 \%$ of spleen, and $6.7 \%$ of drumstick samples (Cui et al., 2015). In this same study (Cui et al., 2015), $14.5 \%$ of 117 raw ground turkey samples from the cooperating turkey plant also tested positive for Salmonella: pathogen levels were estimated at $1.9 \mathrm{MPN} / \mathrm{g}$. Mazengia et al. (2014) also reported that ca. $13.3 \%$ of 180 retail ground turkey samples tested positive for Salmonella: pathogen levels for ground turkey, as well as for the other raw turkey products analyzed in this study, collectively ranged from 0.03 to $2.4 \mathrm{MPN} / \mathrm{g}$. As a final example, in a retail survey of ca. 200 total samples of raw ground beef, pork, chicken, and turkey, isolates of Salmonella were recovered from ca. $20 \%$ of the total samples tested, including 12 of 50 turkey samples (White et al., 2006).

Although Salmonella spp. occur naturally in poultry, at present, cells of this pathogen are not considered adulterants in raw poultry (Hibbard and Kalousi-Tatum, 2020). Due to its widespread occurrence, relatively high prevalence, and at times elevated levels in raw turkey there have been several recalls and a handful of salmonellosis outbreaks, the latter as a result of undercooking or improper handling/storage of raw turkey containing cells of Salmonella. Given that cooking is arguably the most effective intervention for lowering the likelihood of salmonellosis attributed to raw turkey, the objective of this study was to quantify inactivation of Salmonella in turkey burgers of different thicknesses, previously stored refrigerated or frozen, following pan frying in different volumes of cooking oil.

\section{Materials and Methods}

\subsection{Bacterial Strains}

The following nine-strain cocktail of genetic-marked (100 $\mu \mathrm{g}$ rifampicin/mL; TCI America, Portland, OR) strains of Salmonella spp. was used to inoculate raw ground turkey burgers: (i) Salmonella Heidelberg WA17839 (JF6X01.0122, clinical isolate); (ii) Salmonella Heidelberg WA17853 (JF6X01.0122, food isolate); (iii) Salmonella Heidelberg 2011K1224 (JF6X01.0058, ground turkey isolate); (iv) Salmonella Hadar CO-2955; (v) Salmonella Heidelberg FY-14-6 (JF6X01.0045, chicken parts isolate); (vi) Salmonella FSIS Control 1; (vii) Salmonella FSIS Control 2; (viii) Salmonella 
FSIS 38; and (ix) Salmonella FSIS 39. Each strain was maintained and subsequently prepared as a cocktail for this study as previously described (Porto-Fett et al., 2008, 2019; and Luchansky et al., 2020).

\subsection{Inoculation and Cooking of Ground Turkey}

Fresh ground turkey breast was purchased directly from a local producer (Koch's Turkey Farm, Tamaqua, PA) and stored at $-20{ }^{\circ} \mathrm{C}$ until used. Results of the proximate compositional analyses of the ground turkey breast (a 500-g composited portion from each of three trials; $\mathrm{N}=1, \mathrm{n}=3$ ), as conducted by a private testing laboratory according to methods approved and described by the Association of Official Analytical Chemists (AOAC, 2012), were as follows: 0.6 $\pm 0.46 \%$ fat, $72.3 \pm 0.25 \%$ moisture, $25.7 \pm 0.25 \%$ protein, $\mathrm{pH} 5.67 \pm 0.24$, and $\mathrm{a}_{\mathrm{w}} 0.990 \pm 0.001$. The meat was inoculated, formulated, shaped, cooked, and sampled using methods described in our previous studies (Duong et al., 2020; and Luchansky et al., 2013, 2019, 2020). In brief, ground turkey (ca. $13 \mathrm{~kg}$ ) was inoculated with $130 \mathrm{~mL}$ of the Salmonella cocktail to achieve a target level of ca. $6.5 \mathrm{log}$ CFU/g of meat. The inoculated turkey was combined with a spice mixture comprised of salt (1.42\%; SaltWorks Inc., Woodinville, WA), black pepper (0.45\%; The Sausage Maker, Buffalo, NY), garlic powder ( $0.45 \%$; The Sausage Maker), and onion powder ( $0.45 \%$; The Sausage Maker), and then mechanically mixed for ca. $2 \mathrm{~min}$ in a commercial countertop mixer (Univex SRM12; Univex, Salem, $\mathrm{NH}$ ) at room temperature $\left(21 \pm 1^{\circ} \mathrm{C}\right.$ ). Portions of the ground turkey mixture were placed onto a sheet of dry waxed paper (14 x $14 \mathrm{~cm}$; Cabela's, Sidney, NE) within a non-stick press (model UK-516023; Cabela's) to subsequently form patties of uniform thickness [ca. $1.25 \mathrm{~cm}$ (ca. $122 \mathrm{~g}$ ) or ca. $2.5 \mathrm{~cm}$ (ca. $255 \mathrm{~g}$ )] and diameter (ca. $10.5 \mathrm{~cm}$ ). Burgers were placed onto sterile Styrofoam trays (1012S; Genpak, Glens Falls, NY) that were subsequently inserted individually into nylon-polyethylene bags (Koch Supplies, Kansas City, MO). After heat sealing, packages of burgers were then held at $4{ }^{\circ} \mathrm{C}$ for up to $18 \mathrm{~h}$ or at $-20{ }^{\circ} \mathrm{C}$ for up to $30 \mathrm{~d}$ since both "types/states" of turkey burgers are available for purchase at food retailers. Prior to freezing, a single Type J thermocouple (model 304-J-MO 127 125; Omega Engineering, Stamford, CT) was inserted from the side of each burger into the approximate geometric center. Otherwise similar burgers, inoculated but not cooked, were used as controls.

The inoculated ground turkey burgers were cooked to target internal temperatures of $57.2^{\circ} \mathrm{C}\left(135^{\circ} \mathrm{F}\right), 65.6^{\circ} \mathrm{C}\left(150^{\circ} \mathrm{F}\right)$, $73.9^{\circ} \mathrm{C}\left(165^{\circ} \mathrm{F}\right)$, or $82.2^{\circ} \mathrm{C}\left(180^{\circ} \mathrm{F}\right)$, in a non-stick sauté pan $(30.5 \mathrm{~cm}$ diameter $\mathrm{x} 4 \mathrm{~cm}$ depth; Tefal Professional E9380894; Rumilly, Haute-Savoie, France) containing canola oil (15 mL or $30 \mathrm{~mL}$; Refined Expeller Pressed, Whole Foods Market, Austin, TX) on a countertop induction burner (Duxtop 8100MC; Secura, Brookfield, WI) maintained at ca. $175^{\circ} \mathrm{C}$ (ca. $350^{\circ} \mathrm{F}$; medium-high heat) as per the instructions on the product label. Burgers were pan fried based on information collected from the labels of 28 packages of ground turkey purchased at retail (see below). For practical purposes there was no appreciable difference in depth of oil (ca. $0.2 \mathrm{~mm}$ depth) whether $15 \mathrm{or} 30 \mathrm{~mL}$ of oil were added to the pan. A single thermocouple (Type J) was inserted into the approximate geometric centre from the side of each burger. An additional Type $\mathrm{J}$ thermocouple was used to record the surface temperature of the pan itself. All temperatures were monitored continuously in $5 \mathrm{~s}$ intervals via thermocouples connected to an eight-channel thermocouple logger (model OM-CPOCTTEMP; Omega).

As for our related studies using beef- and plant-based products (Luchansky et al., 2020), burgers were flipped every ca. 2 min with the aid of two stainless steel spatulas until the target internal temperature was achieved. Periodic flipping of burgers presumably facilitates more uniform heat transfer and lessens the likelihood that the surface of a burger would be overdone (i.e., charred, crusted, or burned). Once cooked, burgers were placed onto a polystyrene foam packaging tray (Koch Supplies, Kansas City, MO) and weighed. Within ca. $15 \mathrm{~s}$ after weighing, up to eight additional temperatures were recorded using a handheld Type K digital thermocouple (Model AquaTuff Waterproof 351 Digital Thermocouple; Cooper Atkins, Middlefield, CT) to chronicle temperature variations at several locations within each burger as soon as possible after cooking. Doing so enabled reporting of attendant temperature ranges and averages for a specific endpoint temperature, as well as the identification of potential cold spots within each cooked burger. Next, cooked burgers were transferred into filtered stomacher bags (Type XX-C003; Microbiology International, Frederick, MD), placed on ice, and then sampled within 30 min for surviving Salmonella cells as described (Luchansky et al., 2020).

\subsection{Microbiological Analyses of Inoculated Burgers After Cooking}

Salmonella were enumerated from uncooked and cooked burgers by macerating each less thick burger (ca. $1.25 \mathrm{~cm}$; ca. $95 \mathrm{~g}$ after cooking) in $100 \mathrm{~mL}$ and each thicker burger (ca. $2.5 \mathrm{~cm}$; ca. $210 \mathrm{~g}$ after cooking) in $200 \mathrm{~mL}$ of sterile $0.1 \%$ peptone (Difco; Becton, Dickinson Company, Sparks, MD) water as described (Luchansky et al., 2020). Previous studies by our group (Calle et al., 2015; Data not shown) established that some (heat injured) cells of Salmonella were not recoverable 
on XLT4 agar in comparison to TSA agar; however, this difference was not appreciable $(<0.5 \log \mathrm{CFU} / \mathrm{g})$. In addition, when pathogen levels decreased to below a detection limit by direct plating, for statistical analyses (see below) of these data, the detection limit of $<0.34 \log \mathrm{CFU} / \mathrm{g}$ was used as the $\log \mathrm{CFU} / \mathrm{g}$ value for both positive and negative enrichments as described (Ihnot et al., 1998).

\subsection{Survey of poultry burgers available at retail}

For the purpose of this study, an informal, non-randomized survey was conducted at food retailers within the vicinity of Raleigh, NC, to collect general information about the appliance used and recommended endpoint temperature for cooking turkey burgers. Another survey was conducted at food retailers in PA an NJ within the vicinity of Wyndmoor, PA, to collect general information about the state of burgers (i.e., refrigerated versus frozen), types of packaging, label information (i.e., handling and cooking instructions, list of ingredients), and the size and formulation of poultry burgers available for purchase. As part of the NC survey, a total of 28 samples of ground turkey were purchased. For the PA and NJ survey, a total of 36 samples/burgers (18 brands), that being 29 ground turkey and seven ground chicken burgers, were purchased at 10 large chain stores and two specialty stores/meat markets during four shopping trips over a twoweek period in Spring of 2017. Stores were selected based on convenience and proximity to our laboratories, and because the stores selected provided good representation of locations from where a considerable number of consumers would purchase turkey burgers.

\subsection{Statistical analyses}

Means and standard deviations were calculated from data for each trial using the Microsoft Excel 2010 software (Redmond, WA). A total of 228 cooked (i.e., experimental) and 18 uncooked (i.e., control) burgers were analyzed from among three trials and three replicates per experimental treatment $(\mathrm{N}=3, \mathrm{n}=3$ ). The SAS system (SAS Version 9.4; SAS Institute, Cary, NC) was used to analyze and determine statistical significance among the following factors: volume of oil, burger weight/thickness, state of burger prior to cooking, and cooking temperatures. Analysis of Variance (ANOVA) was used to determine the effects and interactions of the abovementioned factors on the log reduction values using the PROC MIXED procedure. Differences in lethality observed for cooking oil volume, burger weight/thickness, state of the burger prior to cooking, and cooking temperatures and/or combinations thereof were considered as significant using the Sidak method at the $p=0.05$ significance level.

\section{Results}

\subsection{Survey of Poultry Burgers Available at Retail}

Regarding our survey of turkey burgers available for purchase at food retailers in NC, more labels recommended that burgers should be pan fried rather than grilled or broiled (Data not shown). Regarding our survey of turkey burgers available for purchase at food retailers in PA and NJ, most of the burgers $(80.6 \% ; 29$ of 36) were pre-formed by processors, whereas $19.4 \%$ ( 7 of 36) of the burgers were formed at the store. None of the burgers were breaded, and none of the burgers were ready-to-eat. For pre-formed burgers, $72.4 \%$ (21 of 29) of the samples were sold frozen and 27.6\% (8 of 29) were sold refrigerated. However, for burgers that were formed at the store, most $(85.7 \% ; 6$ of 7$)$ were sold as refrigerated; only one sample was sold as frozen. Regarding packaging, 5.6\% (2 of 36) of the samples were hand-wrapped in butcher paper, $41.7 \%$ (15 of 36) were overwrapped with film on a foam tray, and 52.8\% (19 of 36) were packaged on a plastic tray that was wrapped with a plastic film under a modified atmosphere. Most burgers were round (86.1\%; 31 of 36), followed by burgers with "flower" (8.3\%; 3 of 36) and "oval" (5.6\%; 2 of 36) shapes. The average fat content and weight as listed on the label were $8.0 \pm 2.6 \mathrm{~g}$ (ranging from 3.6 to $14.1 \mathrm{~g}$ ) and $132.9 \pm 29.2 \mathrm{~g}$ (ranging from 83.5 to $214 \mathrm{~g}$ ), respectively, whereas the diameter and thickness of burgers were $10.4 \pm 1.1 \mathrm{~cm}$ (ranging from 7.5 to $12.5 \mathrm{~cm}$ ) and $1.25 \pm 0.4 \mathrm{~cm}$ (ranging from ca. 0.5 to $2.0 \mathrm{~cm}$ ), respectively.

All ground chicken and ground turkey burgers displayed safe handling instructions on the package label. Examples of suggested safe handling instructions were: (i) "some food products may contain bacteria that could cause illness if the product is mishandled or cooked improperly"; (ii) "for your protection, follow these safe handling instructions: keep refrigerated or frozen"; (iii) "thaw in refrigerator or microwave"; (iv) "keep raw meat and poultry separate from other foods"; (v) "wash working surfaces including cutting boards, utensils and hands after touching raw meat or poultry"; and (vi) "cook thoroughly". Regarding cooking instructions/recommendations, only four of the 36 samples (11.1\%) did not display any cooking recommendations, whereas $88.9 \%$ (32 of 36) recommended to: (i) cook burgers thoroughly to a specified internal temperature such as $165^{\circ} \mathrm{F}\left(69.4 \%\right.$; 25 of 32 samples) or $170{ }^{\circ} \mathrm{F}(12.5 \%$; 4 of 32 samples $)$; (ii) cook burgers thoroughly, but did not state a target internal temperature (3.1\%; 1 of 32 samples); (iii) cook by time per side 
(3.1\%; 1 of 32 samples); or (iv) cook until browned on both sides and to "desired doneness" in the middle (2.9\%; 1 of 32 samples). Of the 36 burgers surveyed, $13.9 \%$ ( 5 of 36) did not have any ingredients listed on the label. For those burgers that had ingredients listed on the label, the most common ingredients added to the formulation of chicken and turkey burgers were: salt $(71 \%, 22$ of 31), rosemary extract $(58.1 \%$; 18 of 31), natural flavoring $(48.4 \%$; 15 of 31$)$, garlic powder $(35.5 \%, 11$ of 31$)$, and/or onion powder $(32.3 \%, 10$ of 31). Some burgers also contained ingredients that imparted functionality such as flavor enhancers (e.g., hydrolyzed corn protein, autolyzed yeast extract, or corn syrup solids), vitamins (e.g., thiamine hydrochloride), preservatives (e.g., lactic acid or sorbic acid), or binding agents (e.g., bread crumbs, potassium or sodium phosphate, milk protein, or sodium bicarbonate).

\subsection{Cooking times and cooking temperatures}

Overall, the times required to achieve the target internal temperatures of $57.2,65.6,73.9$, or $82.2^{\circ} \mathrm{C}$ were significantly longer $(p<0.05)$ for frozen turkey burgers when compared to refrigerated burgers. In addition, regardless of the initial state of the burgers (i.e., refrigerated or frozen) or volume of oil (i.e., 15 or $30 \mathrm{~mL}$ ), the cooking times required to achieve the target internal temperatures within $2.5 \mathrm{~cm}$ thick burgers were significantly longer $(p<0.05)$ when compared to results for otherwise similar burgers that were $1.25 \mathrm{~cm}$ thick. Also, the higher the internal target temperature, the longer $(p<0.05)$ the time needed for cooking either refrigerated and frozen burgers. Irrespective of the volume of oil used, the time required for cooking refrigerated burgers to internal temperatures of $57.2^{\circ} \mathrm{C}$ to $82.2^{\circ} \mathrm{C}$ ranged from 4.9 to 8.0 min for 1.25 $\mathrm{cm}$ thick burgers compared with 12.2 to $20.3 \mathrm{~min}$ for $2.5 \mathrm{~cm}$ thick burgers. For frozen burgers, the time required for achieving the target internal temperatures ranged from 7.0 to $12.7 \mathrm{~min}$ ( $1.25 \mathrm{~cm}$ thick) to 20.8 to $31.9 \mathrm{~min}(2.5 \mathrm{~cm}$ thick).

Regarding the variability and range of cooking temperatures achieved within turkey burgers (Table 1), there was no association between the volume of oil, thickness of burgers, or state of burgers prior to cooking and the internal burger temperatures. Irrespective of the volume of cooking oil used, when $1.25 \mathrm{~cm}$ thick burgers, previously stored refrigerated, were cooked to internal temperatures of $57.2,65.6,73.9$, or $82.2^{\circ} \mathrm{C}$, the average final internal temperature readings were $67.5 \pm 8.5^{\circ} \mathrm{C}, 77.2 \pm 11.2^{\circ} \mathrm{C}, 80.5 \pm 7.7^{\circ} \mathrm{C}$, or $86.5 \pm 6.3^{\circ} \mathrm{C}$, respectively. When $2.5 \mathrm{~cm}$ thick burgers, previously stored refrigerated, were cooked to $57.2,65.6,73.9$, or $82.2^{\circ} \mathrm{C}$, the average final internal temperatures were $67.2 \pm 11.9^{\circ} \mathrm{C}, 75.2 \pm$ $11.2^{\circ} \mathrm{C}, 80.2 \pm 8.4{ }^{\circ} \mathrm{C}$, or $85.7 \pm 6.1{ }^{\circ} \mathrm{C}$, respectively. Likewise, the average final internal temperatures within frozen burgers formed to a thickness of $1.25 \mathrm{~cm}$ and pan fried in 15 or $30 \mathrm{~mL}$ of canola oil to target temperatures of 57.2, 65.6, 73.9, or 82.2 ${ }^{\circ} \mathrm{C}$ were $61.6 \pm 5.3{ }^{\circ} \mathrm{C}, 67.2 \pm 5.3{ }^{\circ} \mathrm{C}, 74.3 \pm 5.8^{\circ} \mathrm{C}$, or $81.8 \pm 5.6^{\circ} \mathrm{C}$, respectively. For frozen burgers formed to a thickness

\section{Table 1: Internal Temperatures in Fresh and Frozen Turkey Burgers Cooked to Endpoint Temperatures of 57.2,}

65.6, 73.9, or $82.2{ }^{\circ} \mathrm{C}(\mathrm{N}=3, \mathrm{n}=3)$

\begin{tabular}{|c|c|c|c|c|c|}
\hline \multirow{2}{*}{$\begin{array}{c}\text { Thick- } \\
\text { ness } \\
(\mathbf{c m})\end{array}$} & \multirow{2}{*}{$\begin{array}{c}\text { Volume } \\
\text { of Oil } \\
(\mathrm{mL})\end{array}$} & \multicolumn{4}{|c|}{ Target End Point Temperature $\left({ }^{\circ} \mathrm{C}\right)$} \\
\hline & & 57.2 & 65.6 & 73.9 & 82.2 \\
\hline \multirow[t]{2}{*}{1.25} & 15 & $66.3 \pm 7.3^{1,2}(49.2-80.8)^{3}$ & $77.6 \pm 8.4(55.5-95.8)$ & $80.1 \pm 8.3(56.8-95.5)$ & $87.2 \pm 6.0(65.5-97.8)$ \\
\hline & 30 & $68.8 \pm 9.4(47.2-95.5)$ & $76.7 \pm 26.2(56.8-99.4)$ & $80.7 \pm 7.1(64.9-98.5)$ & $86.1 \pm 5.94(73-99.4)$ \\
\hline \multirow[t]{2}{*}{2.5} & 15 & $68.4 \pm 12.0(53.3-94.5)$ & $74.2 \pm 11.6(51.1-96.6)$ & $80.8 \pm 8.6(55.5-98.4)$ & $85.8 \pm 6.5(62.2-98.3)$ \\
\hline & 30 & $65.9 \pm 11.7(50.2-96.2)$ & $76.1 \pm 10.9(49.6-98.6)$ & $79.7 \pm 8.2(55.2-96.9)$ & $85.3 \pm 6.2(74.5-100.1)$ \\
\hline
\end{tabular}

Note: ${ }^{1}$ For a given temperature, thickness of burger, volume of cooking oil, and for both refrigerated and frozen burgers, the internal temperatures reported represent the average of the target temperature achieved while burgers were in the frying pan as determined via a Type $\mathrm{J}$ thermocouple plus 8 additional temperatures within each burger that were taken using a hand-held Type $\mathrm{K}$ digital thermocouple immediately after burgers were removed from the frying pan.

${ }^{2}$ Mean \pm standard deviation.

${ }^{3}$ Range of minimum and maximum internal temperatures.

of $2.5 \mathrm{~cm}$ and irrespective of cooking oil volume, the average final internal temperatures following cooking to 57.2, 65.6, 73.9 , or $82.2^{\circ} \mathrm{C}$ were $61.6 \pm 7.1^{\circ} \mathrm{C}, 67.3 \pm 7.2^{\circ} \mathrm{C}, 75.8 \pm 5.9^{\circ} \mathrm{C}$, or $81.6 \pm 5.2^{\circ} \mathrm{C}$, respectively.

\subsection{Thermal Inactivation of Salmonella spp. in Turkey Burgers}

For a given cooking temperature, state of meat, or burger thickness, with the exception of $2.5 \mathrm{~cm}$ thick refrigerated burgers cooked to $82.2^{\circ} \mathrm{C}$, there was no significant $(p>0.05)$ effect of the volume of cooking oil on thermal inactivation of Salmonella. Regarding the effect of the state of meat on inactivation of Salmonella, with the exception of $1.25 \mathrm{~cm}$ thick burgers that were cooked to $57.2^{\circ} \mathrm{C}$ in $15 \mathrm{~mL}$ of oil or cooked to $65.6^{\circ} \mathrm{C}$ in $30 \mathrm{~mL}$ of oil, significantly $(p<0.05)$ more 
cells of Salmonella were inactivated after cooking refrigerated burgers when compared to frozen burgers. Likewise, for $2.5 \mathrm{~cm}$ thick burgers, significantly $(p<0.05)$ more cells of Salmonella were inactivated in refrigerated burgers when compared to frozen burgers that were cooked to $65.6,73.9$, or $82.2^{\circ} \mathrm{C}$ in $30 \mathrm{~mL}$ of oil. However, no significant $(p>0.05)$ differences in pathogen lethality were observed between $2.5 \mathrm{~cm}$ thick refrigerated or frozen burgers that were cooked to $57.2,65.6,73.9$, or $82.2^{\circ} \mathrm{C}$ in $15 \mathrm{~mL}$ of oil or to $57.2^{\circ} \mathrm{C}$ in $30 \mathrm{~mL}$ of oil.

Regarding the effect of burger thickness on pathogen inactivation, significantly $(p<0.05)$ more cells of Salmonella were inactivated in previously refrigerated $1.25 \mathrm{~cm}$ thick burgers cooked to 57.2 or $65.6{ }^{\circ} \mathrm{C}$ in $15 \mathrm{~mL}$ of oil or that were cooked to $57.2^{\circ} \mathrm{C}$ in $30 \mathrm{~mL}$ of oil when compared to previously refrigerated $2.5 \mathrm{~cm}$ thick burgers cooked to the same endpoint temperatures and in the same volume of oil. Similarly, significantly $(p<0.05)$ more cells of Salmonella were inactivated in previously frozen $1.25 \mathrm{~cm}$ thick burgers cooked to $65.6^{\circ} \mathrm{C}$ in $30 \mathrm{~mL}$ of oil when compared to previously frozen $2.5 \mathrm{~cm}$ thick burgers cooked to the same endpoint temperature and in the same volume of oil. Lastly, for $1.25 \mathrm{~cm}$ thick burgers, cooking temperatures of $65.6,73.9$, or $82.2{ }^{\circ} \mathrm{C}$ were significantly $(p<0.05)$ more effective at inactivating the pathogen than cooking to an endpoint temperature of $57.2^{\circ} \mathrm{C}$ for refrigerated burgers cooked in $15 \mathrm{~mL}$ of oil or in frozen burgers cooked in $30 \mathrm{~mL}$ of oil. In addition, no statistical differences $(p>0.05)$ were noted for thermal inactivation of Salmonella in previously refrigerated $1.25 \mathrm{~cm}$ thick burgers that were cooked in $30 \mathrm{~mL}$ of oil to $57.2,65.6$, or $82.2^{\circ} \mathrm{C}$ when compared with otherwise similar burgers cooked to $73.9^{\circ} \mathrm{C}$. Similarly, no statistical differences $(p>0.05)$ were noted for thermal inactivation of Salmonella in previously frozen $1.25 \mathrm{~cm}$ thick burgers cooked in $15 \mathrm{~mL}$ of oil that were cooked to $57.2^{\circ} \mathrm{C}$ when compared with otherwise similar burgers cooked to $65.6{ }^{\circ} \mathrm{C}$. However, significant differences $(p>0.05)$ were noted when frozen $1.25 \mathrm{~cm}$ thick burgers cooked to $57.2^{\circ} \mathrm{C}$ in $15 \mathrm{~mL}$ of oil were compared with similar burgers that were cooked to 73.9 and $82.2^{\circ} \mathrm{C}$. No statistical differences $(p>0.05)$ were noted for thermal inactivation of Salmonella among previously frozen $1.25 \mathrm{~cm}$ thick burgers cooked in $15 \mathrm{~mL}$ of oil that were cooked to $65.6^{\circ} \mathrm{C}$ when compared with otherwise similar burgers cooked to 73.9 or $82.2^{\circ} \mathrm{C}$. Likewise, for $2.5 \mathrm{~cm}$ thick burgers, stored either refrigerated or frozen, that were cooked in $15 \mathrm{~mL}$ of cooking oil or frozen $2.5 \mathrm{~cm}$ thick burgers that were cooked in $30 \mathrm{~mL}$ of oil, significantly $(p<0.05)$ more cells of Salmonella were inactivated at temperatures of 73.9 or $82.2^{\circ} \mathrm{C}$ when compared to endpoint temperatures of 57.2 or $65.6^{\circ} \mathrm{C}$. For previously refrigerated $2.5 \mathrm{~cm}$ thick burgers that were cooked in $30 \mathrm{~mL}$ of oil, significantly $(p<0.05)$ more cells of Salmonella were inactivated at endpoint temperatures of $65.6,73.9$, or $82.2^{\circ} \mathrm{C}$ when compared to $57.2^{\circ} \mathrm{C}$, albeit with cooking to an end point temperature of $82.2^{\circ} \mathrm{C}$ being significantly $(p<0.05)$ more effective at inactivating the pathogen than cooking to endpoint temperatures of 65.6 or $73.9^{\circ} \mathrm{C}$.

Irrespective of the volume of oil, state of the meat prior to cooking, or weight/thickness of the burger, pan frying inoculated turkey burgers to target internal temperatures of 73.9 or $82.2^{\circ} \mathrm{C}$ resulted in total reductions of resulted in $>5.0$ $\log \mathrm{CFU} / \mathrm{g}$ in Salmonella numbers. When cooking to an internal temperature of $65.6{ }^{\circ} \mathrm{C}$, and irrespective of oil volume, total reductions of $>5.6 \log \mathrm{CFU} / \mathrm{g}$ were also achieved for $1.25 \mathrm{~cm}$ thick burgers that were stored refrigerated prior to cooking. In contrast, when otherwise similar but thicker $(2.5 \mathrm{~cm})$ burgers, previously stored refrigerated, were cooked to $65.6^{\circ} \mathrm{C}$ in 15 or $30 \mathrm{~mL}$ of oil, pathogen numbers were reduced by ca. 3.7 or $4.9 \log \mathrm{CFU} / \mathrm{g}$, respectively. Likewise, regardless of oil volume or burger thickness, pan frying frozen turkey burgers to an internal temperature of $65.6^{\circ} \mathrm{C}$ resulted in reductions of ca. 3.4 to $4.6 \mathrm{log} \mathrm{CFU} / \mathrm{g}$ in Salmonella numbers. When cooking to an internal temperature of $57.2^{\circ} \mathrm{C}$, and irrespective of oil volume, total reductions of ca. $4.8 \mathrm{log} \mathrm{CFU} / \mathrm{g}$ were achieved for $1.25 \mathrm{~cm}$ thick burgers that were stored refrigerated prior to cooking. However, when otherwise similar but thicker $(2.5 \mathrm{~cm})$ burgers, previously stored refrigerated, were cooked to $57.2^{\circ} \mathrm{C}$ in 15 or $30 \mathrm{~mL}$ of oil, pathogen numbers were reduced by ca. $2.8 \mathrm{log} \mathrm{CFU} / \mathrm{g}$. Lastly, irrespective of thickness, total reductions of ca. 2.4 to $3.2 \log \mathrm{CFU} / \mathrm{g}$ in pathogen numbers were observed when previously frozen burgers were pan fried to $57.2^{\circ} \mathrm{C}$ in 15 or $30 \mathrm{~mL}$ of canola oil.

For refrigerated burgers, irrespective of cooking oil volume or burger thickness, it was not possible to recover cells of Salmonella by direct plating or by enrichment from $86.9 \%$ (33 of 38 burgers) and $81.6 \%$ ( 31 of 38 burgers) of burgers cooked to 73.9 and $82.2^{\circ} \mathrm{C}$, respectively (Data not shown). In contrast, for burgers previously refrigerated and cooked to 57.2 or $65.6^{\circ} \mathrm{C}$ cells of Salmonella were not recovered by direct plating or by enrichment from $13.9 \%$ ( 5 of 36 burgers) or $48.7 \%$ (19 of 39 burgers) of burgers, respectively (Data not shown). Likewise, irrespective of cooking oil volume or burger thickness, when frozen burgers were cooked to 73.9 or $82.2^{\circ} \mathrm{C}$, cells of Salmonella were not recovered by direct plating or by enrichment from $83.3 \%$ (30 of 36 burgers) or $81.6 \%$ (31 of 38 burgers) of burgers, respectively. Lastly, the pathogen was not recovered by direct plating or by enrichment from $20 \%$ ( 8 of 40 burgers) and $42.5 \%$ ( 17 of 40 burgers) of previously frozen turkey burgers subsequently cooked to 57.2 and $65.6{ }^{\circ} \mathrm{C}$, respectively.

As assessed empirically, and regardless of the volume of oil, thickness of burgers, or storage temperature of burgers prior to cooking, when turkey burgers were cooked to an internal temperature of 73.9 or $82.2^{\circ} \mathrm{C}$ all nine burgers per each 
treatment displayed the characteristic "white color" expected for a fully-cooked poultry burger. Likewise, no pinkish spots were observed in $1.25 \mathrm{~cm}$ thick burgers stored refrigerated or frozen and subsequently cooked in 15 or $30 \mathrm{~mL}$ of oil to an internal temperature of $65.6^{\circ} \mathrm{C}$. However, for $2.5 \mathrm{~cm}$ thick burgers stored refrigerated and subsequently cooked to an internal temperature of $65.6^{\circ} \mathrm{C}$ in 15 or $30 \mathrm{~mL}$ of oil, $66.7 \%$ (6 of 9) or $27 \%$ (3 of 11) of burgers, respectively, displayed pink/pinkish spots throughout the burger. For $1.25 \mathrm{~cm}$ thick burgers stored refrigerated and subsequently cooked in 15 $\mathrm{mL}$ of oil to an internal temperature of $57.2^{\circ} \mathrm{C}$, all nine burgers displayed pink/pinkish spots throughout, whereas for otherwise similar burgers cooked in $30 \mathrm{~mL}$ of oil only $33.3 \%$ (3 of 9) displayed pink/pinkish spots. Lastly, for $2.5 \mathrm{~cm}$ thick burgers cooked to an internal temperature of $57.2^{\circ} \mathrm{C}$, and regardless of the volume of oil or storage temperature, all nine burgers displayed pink/pinkish spots.

\section{Discussion}

Much is commonly known and much has been published in scientific journals on the formulation, nutritional and health benefits, sensory/quality attributes, and handling/safety of beef burgers, whereas related information on turkey burgers is lacking, especially as it relates to the behavior and persistence of microbial pathogens. In a ranking of the health burden of the top 50 pathogen-food combinations based on both cost of illness and loss of Quality Adjusted Life Years (QALYs), Batz et al. (2012) ranked “Campylobacter-poultry" and "S. enterica-poultry" as first and fourth, respectively, on this list. Nonetheless, there has been a continued increase in consumer demand for poultry, in general, due its preferred taste, texture, and/or presumed health and nutritional benefits over other protein sources, notably its beef counterpart, with chicken being consumed in 2020 at ca. $95 \mathrm{lbs}$ per capita in the US and with beef coming in second and being consumed at ca. 58 lbs (Wong et al., 1993; and Leake, 2021). An unintended consequence of poultry's increased popularity has been a concomitant increase in the price of ground turkey, typically making it more costly than ground beef (Munoz, 2021). Thus, additional studies are warranted to elaborate the time and temperature combinations required to deliver an appreciable reduction of cells of Salmonella during cooking of turkey-based burgers.

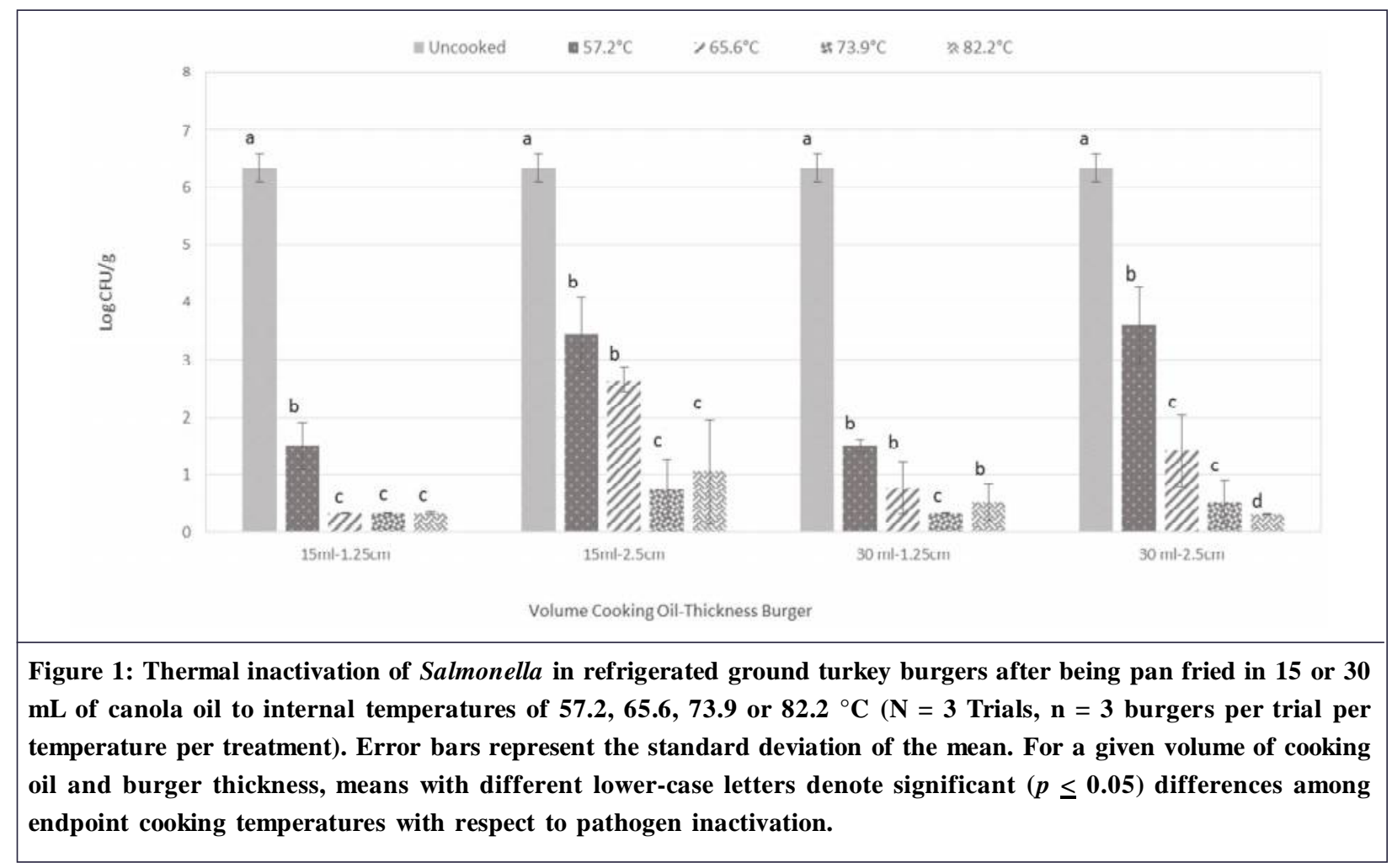

We quantified the fate of Salmonella spp. in turkey burgers following pan frying to temperatures ranging from 57.6 to $82.2^{\circ} \mathrm{C}$. Parameters evaluated in addition to cooking temperatures included the state of the burgers just prior to cooking (i.e., refrigerated or frozen), the volume of cooking oil added to the frying pan, and the thickness of each burger. As is evident by comparing the data in Figures 1 and 2, there was a significant $(p<0.05)$ difference in the initial levels of Salmonella between uncooked burgers stored refrigerated $\left(4{ }^{\circ} \mathrm{C}\right)$ versus stored frozen $\left(-20{ }^{\circ} \mathrm{C}\right)$ : pathogen levels in refrigerated burgers just prior to cooking were ca. $6.3 \pm 0.25 \mathrm{log} \mathrm{CFU} / \mathrm{g}$, whereas in frozen burgers levels of Salmonella just prior to cooking were ca. $5.3 \pm 0.29 \mathrm{log}$ CFU/g. Dominguez and Schaffner (2009) reported that levels of Salmonella remained relatively constant in chicken nuggets and chicken strips during storage at $-20{ }^{\circ} \mathrm{C}$ for up to $112 \mathrm{~d}$. Manios and 
Skandamis (2015) also reported that storing ground beef patties ( $20 \%$ fat) for $5 \mathrm{~d}$ at $-22{ }^{\circ} \mathrm{C}$ resulted in only a ca. $0.7 \mathrm{log}$ $\mathrm{CFU} / \mathrm{g}$ decrease in Salmonella levels, with no additional reduction in pathogen numbers after $75 \mathrm{~d}$. As a final example, Dykes and Moorhead (2001) reported that Salmonella viability was not appreciably affected when beef trimmings were held frozen at $-18^{\circ}$ or $-35^{\circ} \mathrm{C}$ for up $270 \mathrm{~d}$. Given these nominal reductions in pathogen levels due to freezing as observed herein and reported elsewhere, neither the rate nor the effect of freezing on viability of Salmonella over $30 \mathrm{~d}$ of frozen storage were monitored herein. Regardless, the comparative reductions in levels of Salmonella were based on differences in the initial levels of the pathogen that were quantified in uncooked burgers (refrigerated or frozen) compared to remaining levels after cooking. As such, it is possible to directly compare the resulting lethality of pan frying refrigerated (Figure 1) and frozen (Figure 2) turkey burgers to internal temperatures of $57.6,65.6,73.9$, or $82.2^{\circ} \mathrm{C}$ on viability of Salmonella.

It is well established that cooking is the most effective consumer practice to eliminate foodborne pathogens that at times may be present in raw meat and poultry products. The USDA FSIS recommends that consumers cook beef burgers to $71.1^{\circ} \mathrm{C}\left(160^{\circ} \mathrm{F}\right)$ to eliminate pathogens (USDA, 2012), whereas turkey burgers must be cooked to an instantaneous internal temperature of at least $73.9^{\circ} \mathrm{C}\left(165^{\circ} \mathrm{F}\right)$ to eliminate the relatively low levels of Salmonella that on occasion may be present (USDA, 2013, 2020). As detailed herein and elsewhere (Routh et al., 2015; Chai et al., 2017; CDC, 2019; and Hassan et al., 2019), over the past decade or so there have been several recalls and illnesses attributed to consumption of (undercooked and/or improperly handled) ground chicken and turkey due to contamination with cells of Salmonella. The associated integrated risk of public health is exacerbated because Salmonella are somewhat tolerant of heat, with select strains being capable of surviving some thermal processing (Matthews et al., 2017). Numerous studies have reported on thermal resistance (i.e., D-values) of Salmonella in poultry products such as ground turkey breast and thighs and ground chicken breast and skin, as well as for chicken burgers or chicken tenders (Juneja et al., 2001; Mazzotta, 2000; Murphy et al., 2000, 2002, 2004a, 2004b; Takhar et al., 2009; Tuntivanich et al., 2008; Veeramuthu et al., 1998). For example, D-values of 43.1 to $0.096,43.8$ to 0.07 , and 43.3 to 0.09 min were reported for ground turkey (ca. $5.4 \%$ fat; 5-g each at ca. $1 \mathrm{~mm}$ thick), chicken thigh/leg meat (ca. 10.3\% fat; 10-g each at ca. $1 \mathrm{~mm}$ thick), and chicken skin (ca. 47.4\% fat; ca. 5-g each at ca. $1 \mathrm{~mm}$ thick), respectively, inoculated with Salmonella and placed within a vacuum-sealed plastic bag that was subsequently cooked to 55 to $70{ }^{\circ} \mathrm{C}$ in a circulating water bath (Murphy et al., 2004a and 2004b). Mazzota (2000) also reported D-values of 3.2 to $0.18 \mathrm{~min}$ for Salmonella inoculated into ground chicken breast (5-g each at ca. $0.5 \mathrm{~mm}$ thick) heated to 56 to $63{ }^{\circ} \mathrm{C}$ in a thermostatically-controlled water bath. With the exception of a handful of publications (Baker et al., 1983; Luchansky et al., 2020; Matthews et al., 2017; Murphy et al., 1999 and 2001), thermal inactivation studies of Salmonella directly in burgers have been almost exclusively conducted using ground beef or ground chicken. For example, reductions of ca. 4.0 to $>6.0 \mathrm{log}$ CFU/g in levels of Salmonella in ground beef burgers were observed when cooked to $>71.1^{\circ} \mathrm{C}$ (Luchansky et al., 2020; Matthews et al., 2017), whereas reductions of ca. 3.0 to $>6.0$ $\log \mathrm{CFU} / \mathrm{g}$ were observed for ground chicken burgers cooked to endpoint temperatures of $>70{ }^{\circ} \mathrm{C}$ (Baker et al., 1983; Murphy et al., 1999, 2001; Matthews et al., 2017). In a related study (Luchansky et al., 2020), we demonstrated that pan frying plant-based (15.6\% fat) versus beef-based (16.2\% fat) burgers in $15 \mathrm{~mL}$ of canola oil to internal temperatures of $62.8,68.3$, or $73.9^{\circ} \mathrm{C}$ decreased Salmonella numbers by ca. 3.5, 5.4, or $6.5 \log \mathrm{CFU} / \mathrm{g}$, respectively.

Our results validated that cooking inoculated turkey burgers ( $<1 \%$ fat $)$ on a non-stick frying pan to the recommended internal temperature of $>73.9^{\circ} \mathrm{C}$ (USDA, 2013, 2020), irrespective of the cooking oil volumes or burger thicknesses tested, delivered a>5.0 log reduction in numbers of Salmonella. It should be noted that levels of surviving Salmonella were likely underestimated, since XLT4 is a particularly harsh recovery medium: the diversity and high levels of the indigenous background flora within raw ground turkey necessitated the use of XLT4 agar plus rifampicin to recover (surviving) cells of Salmonella comprising the pathogen cocktail that was inoculated into burgers. That being said, samples were enriched to assess the presence/absence of surviving cells of Salmonella. Our results are in general agreement with previous studies reporting on the efficacy of consumer cooking practices for inactivation of Salmonella in burgers prepared from turkey. For example, Murphy etal. (2004a) validated that a 7.0-log reduction in Salmonella numbers was achieved when turkey burgers (ca. $5.5 \%$ fat; ca. $1.3 \mathrm{~cm}$ thick and ca. $12.7 \mathrm{~cm}$ diameter) were cooked to an internal temperature of $70{ }^{\circ} \mathrm{C}$ in an air impingement oven set at $232{ }^{\circ} \mathrm{C}$, with an air velocity of $0.02 \mathrm{~m} / \mathrm{s}$ and $50 \%$ air humidity. Roccato et al. (2015) reported that pan frying turkey burgers (ca. $105 \mathrm{~g}, 1.3 \mathrm{~cm}$ thick and ca. $9.5 \mathrm{~cm}$ diameter) for 5 or $10 \mathrm{~min}$ in $25 \mathrm{~mL}$ of olive oil decreased Salmonella numbers to below detection $(<1.3 \mathrm{MPN} / \mathrm{g})$ from initial inoculation levels of 1.0 to $3.0 \log \mathrm{CFU} / \mathrm{g}$.

Temperature variability within burgers during cooking may be attributed to several factors including the moisture and fat content, formulation (e.g., inclusion of non-meat ingredients such as mushrooms, bacon, grated cheese, etc.), state of the meat prior to cooking (e.g., refrigerated or frozen), weight, diameter, and thickness of burgers, number of 
times burgers are flipped (e.g., single or multiple), and cooking method (e.g., grilled, sautéd, baked, etc.) which, in turn, may have a direct effect on pathogen inactivation (Doyle and Mazzota, 2000; Luchansky et al., 2020, 2013; Mattick et al., 2002; Porto-Fett et al., 2016; Smith et al., 2001; and Tuntivanich et al., 2008). Given the range and variation in temperatures we observed for a given target endpoint cooking temperature, as well as the attendant recovery of sporadic survivors due to presumed cold spots within the meat, our findings also confirm the importance of proper and frequent thermometer use to determine doneness. Further studies are warranted or underway to evaluate additional parameters that could appreciably impact on thermal inactivation of Salmonella within turkey burgers in response to heat, including, but not limited to, strain-to-strain variation, use of pathogen cocktails versus single strains, effect of cooking appliances, and flipping of burgers, as well as burger shape, density, and waffling. In the interim, as reported herein we validated that the USDA FSIS recommended minimum endpoint internal temperature of $73.9^{\circ} \mathrm{C}\left(165^{\circ} \mathrm{F}\right)$ for cooking ground poultry, as measured with a food thermometer (USDA, 2013; and 2020), can appreciably lower levels of Salmonella and significantly lessen the risk of salmonellosis associated with turkey burgers.

Disclosure: Mention of trade names or commercial products in this publication is solely for the purpose of providing specific information and does not imply recommendation or endorsement by the US Department of Agriculture (USDA). The USDA is an equal opportunity provider and employer.

\section{References}

Baker, R.C., Poon, W., and Vadehra, D.V. (1983). Destruction of Salmonella typhimurium and Staphylococcus aureus in poultry products cooked in a conventional and microwave oven. Poultry Sci., 62, 805-810.

Batz, M.B., Hoffmann, S., and Morris, Jr., J.G. (2012). Ranking the disease burden of 14 pathogens in food sources in the United States using attribution data from outbreak investigations and expert elicitation. J. Food Prot., 75, 12781291.

Calle, A., Porto-Fett, A.C.S., Shoyer, B.A., Call, J., Luchansky, J.B., and Thippareddi, H. (2015). Microbiological safety of commercial prime rib preparation methods: thermal inactivation of Salmonella spp. in mechanically tenderized beef roasts. J. Food Prot., 78, 2126-2135.

[CDC] Centers for Disease Control and Prevention. (2011a). Multistate outbreak of human Salmonella Hadar infections associated with turkey burgers (Final update). Retrieved from: https://www.cdc.gov/salmonella/2011/turkeyburger-4-4-2011.html.

[CDC] Centers for Disease Control and Prevention. (2011b). Multistate outbreak of human Salmonella Heidelberg infections linked to ground turkey (Final update). Retrieved from: https:/www.cdc.gov/salmonella/2011/groundturkey-11-10-2011.html.

[CDC] Centers for Disease Control and Prevention. (2019). Outbreak of Salmonella infections linked to Butterball brand ground turkey. Final update. Retrieved from: https://www.cdc.gov/salmonella/schwarzengrund-03-489 19/ index.html\#: : text=Epidemiologic\%20and\%201aboratory\%20evidence\%20indicated,b490 een $\% 20$ contaminated\%20with\%20Salmonella\%20Schwarzengrund.

[CDC] Centers for Disease Control and Prevention. (2021a). Reports of selected Salmonella outbreak investigations. Retrieved from: http://www.cdc.gov/salmonella/outbreaks.html.

[CDC] Centers for Disease Control and Prevention. (2021b). Salmonella outbreak linked to ground turkey. Retrieved from: https://www.cdc.gov/salmonella/hadar-04-496 21/index.html

Chai, S.J., Cole, D., Nisler, A., and Mahon, B.E. (2017). Poultry: the most common food in outbreaks with known pathogens, United States, 1998-2012. Epidemiol Infect., 145, 316-325.

Cui, Y., Guran, H.S., Harrison, M.A., Hofacre, C.L., and Alali, W.Q. (2015). Salmonella levels in turkey neck skins, drumstick bones, and spleens in relation to ground turkey. J. Food Prot., 78, 1945-1953.

Dominguez, S.A., and Schaffner, D.W. (2009). Survival of Salmonella in processed chicken products during frozen storage. J. Food Prot., 72, 2088-2092.

Doyle, A.S., and Mazzota, A.S. (2000). Review of studies on thermal inactivation of salmonellae. J. Food Prot., 63, 779795.

Duong, M.E., Shumaker, T., Cates, S.C., Shelley, L., Goodson, L., Bernstein, C., Lavalle, A., Kirchner, M., Goulter, R., Jaykus, L.-A., and Chapman, B. (2020). An observational study of thermometer use by consumers when preparing ground turkey patties. J. Food Prot., 83, 1167-1174. 
Dykes, G.A., and Moorhead, S.M. (2001). Survival of three Salmonella serotypes on beef trimmings during simulated commercial freezing and frozen storage. J. Food Saf., 21, 87-513 96.

Hassan, R., Buuck, S., Noveroske, D., Medus, C., Sorenson, A., Laurent, J., Rotstein, D., Schlater, L., Freiman, J., Douris, A., Simmons, M., Donovan, D., Henderson, J., Tewell, M., Snyder, K., Oni, O., Von Stein, D., Dassie, K., Leeper, M., Adediran, A., Dowell, N., Gieraltowski, L., and Basler, C. (2019). Multistate outbreak of Salmonella infections linked to raw turkey products - United States, 2017-2019. Morb. Mortal. Wkly. Rep., 68, 1045-1049.

Hibbard, R., and Kalousi-Tatum, M. (2020). Will FSIS declare 31 Salmonella serovars adulterants in meat and poultry? Retrieved from: https://www.foodsafetymagazine.com/magazine-archive1/junejuly-2020/will-fsis 7523 declare-31salmonella-serovars-adulterants-in-meat-and-poultry/.

Ihnot, A.M., Roering, A.M., Wierzba, R.K., Faith, N.G., and Luchansky, J.B. (1998). Behavior of Salmonella typhimurium DT104 during the manufacture and storage of pepperoni. Int. J. Food Microbiol., 40, 117-121.

Juneja, V.K., Eblen, B.S., and Ransom, G.M. (2001). Thermal inactivation of Salmonella spp. in chicken broth, beef, pork, turkey, and chicken: determination of D- and z-values. J. Food Sci., 66, 146-152.

Leake, L.L. (2020). Beefed up: efforts to promote quality and safety in beef abound, from farm-and ranch- fork. Food Qual. Safety, August/September. pp. 12-14.

Luchansky, J.B., Porto-Fett, A.C.S., Shoyer, B.A., Phillips, J., Chen, V., Kause, J., Eblen, D.R., Cook, V.L., Mohr, T.B., Esteban, E., and Bauer, N. (2013). Fate of Shiga toxin 7534 producing O157:H7 and non-O157:H7 Escherichia coli cells within refrigerated, frozen, or frozen then thawed ground beef patties cooked on a commercial open-flame gas and a clam-shell electric grill. J. Food Prot., 76, 1500-1512.

Luchansky, J.B., Mayhew, M., Jung, Y., Klinedinst, A., Harkins, L., Shane, L.E., Osoria, M., McGeary, L., Trauger, Z., Shoyer, B.A., Chapman, B., Cope, S.J., Campano, S.G., and Porto-Fett, A.C.S. (2019). Meat bars: a survey to assess consumer familiarity and preparation parameters and a challenge study to quantify viability of Shiga toxinproducing Escherichia coli cells during processing and storage. J. Food Prot., 82, 1249-542 1264.

Luchansky, J.B., Shoyer, B.A., Jung, Y., Shane, L.E., Osoria, M., and Porto-Fett, A.C.S. (2020). Viability of Shiga toxinproducing Escherichia coli, Salmonella, and Listeria monocytogenes within plant versus beef burgers during cold storage and following pan frying. J. Food Prot., 83, 434-442.

Manios, S.G., and Skandamis, P.N. (2015). Effect of frozen storage, different thawing methods and cooking processes on the survival of Salmonella spp. and Escherichia coli O157:H7 in commercially shaped beef patties. Meat Sci., 1, 25-32.

Matthews, K.R., Kniel, K.E., and Montville, T.J. (2017). Salmonella species. In K.R. Matthews, K.E. Kniel, and T.J. Montville (Eds.), Food microbiology: an introduction (4th ed., pp. 243-260). Washington, DC: ASM Press.

Mattick, K.L., Bailey, R.A., Jørgensen, F., and Humphrey, T.J. (2002). The prevalence and number of Salmonella in sausages and their destruction by frying, grilling, or barbecuing. J. Appl Microbiol., 93, 541-547.

Mazengia, E., Samadpour, M., Hill, H.W., Greeson, K., Tenney, K., Liao, G., Huang, X., and Meschke, J.S. (2014). Prevalence, concentrations, and antibiotic sensitivities of Salmonella serovars in poultry from retail establishments in Seattle, Washington. J. Food Prot., 77, 885-893.

Mazzotta, A.S. (2000). D- and z-values of Salmonella in ground chicken breast meat. J. Food Saf., 20, 217-223.

Munoz, K. (2021). Protein power: 6 easy recipes with ground turkey. Retrieved from: https://www.mensjournal.com/ food-drink/protein-power-recipes-with-ground-turkeybreast/6-turkey-burger/

Murphy, R.Y., Marks, B.P., Johnson, E.R., and Johnson, M.G. (1999). Inactivation of Salmonella and Listeria in ground chicken breast meat during thermal processing. J. Food Prot., 62, 980-985.

Murphy, R.Y., Marks, B.P., Johnson, E.R., and Johnson, M.G. (2000). Thermal inactivation kinetics of Salmonella and Listeria in ground chicken breast meat and liquid medium. J. Food Sci., 65, 706-710.

Murphy, R.Y., Johnson, E.R., Marks, B.P., Johnson, M.G., and Marcy, J.A. (2001). Thermal inactivation of Salmonella senftenberg and Listeria innocua in ground chicken breast patties processed in an air convection oven. Poultry Sci., 80, 515-521.

Murphy, R.Y., Duncan, L.K., Johnson, E.R., Davis, M.D., and Smith, J.N. (2002). Thermal inactivation D- and z-values of Salmonella serotypes and Listeria innocua in chicken patties, chicken tenders, franks, beef patties, and blended beef and turkey patties. J. Food Prot., 65, 53-60. 
Murphy, R.Y., Martin, E.M., Duncan, L.K., Beard, B.L., and Marcy, J.A. (2004a). Thermal process validation for Escherichia coli 0157:H7, Salmonella, and Listeria monocytogenes in ground turkey and beef products. J. Food Prot., 67, 1394-1402.

Murphy, R.Y., Osaili, T., Duncan, L.K., and Marcy J.A. (2004b). Thermal inactivation of Salmonella and Listeria monocytogenes in ground chicken thigh/leg meat and skin. Poultry Sci., 83, 1218-1225.

[OECD] Organisation for Economic Co-Operation and Development (2017). Meat consumption. Retrieved from: http:// data.oecd.org/agroutput/meat-consumption.htm.

Porto-Fett, A.C.S., Call, J.E., and Luchansky, J.B. (2008). Validation of a commercial process for inactivation of Escherichia coli 0157:H7, Salmonella Typhimurium, and Listeria monocytogenes on the surface of whole muscle beef jerky. J Food Prot., 71, 918-589 926.

Porto-Fett, A.C.S., Oliver, M., Daniel, M., Shoyer, B.A., Stahler, L.J., Shane, L.E., Kassama, L.S., Jackson-Davis, A., and Luchansky, J.B. (2016). The effect of deep frying or conventional oven cooking on inactivation of Shiga toxinproducing cells of Escherichia coli (STEC) in meatballs. J. Food Prot., 79, 723-731.

Porto-Fett, A.C.S., Shoyer, B.A., Shane, L.E., Osoria, M., Henry, E., Jung, Y., and Luchansky, J.B. (2019). Thermal inactivation of Salmonella in pâté made from chicken liver. J. Food Prot., 82, 908-987.

Roccato, A., Uyttendaele, M., Cibin, V., Barrucci, F., Cappa, V., Zavagnin, P., Longo, A, and Ricci, A. (2015). Survival of Salmonella Typhimurium in poultry-based meat preparations during grilling, frying and baking. Int. J. Food Microbiol., 197, 1-8.

Rouger, A., Tresse, O., and Zagorec, M. (2017). Bacterial contaminants of poultry meat: sources, species, and dynamics. Microorganisms, 5, 1-17.

Routh, J.A., Pringle, J., Mohr, M., Bidol, S., Arends, K., Adams-Cameron, M., Hancock, W.T., Kissler, B., Rickert, R., Folster, J., Tolar, B., Bosch, S., Behravesh, C.B., Williams, I.T., and Gieraltowski, L. (2015). Nationwide outbreak of multidrug-resistant Salmonella Heidelberg infections associated with ground turkey: United States, 2011. Epidemiol Infect., 143, 3227-3234.

Smith, S.E., Maurer, J.L., Orta-Ramirez, A., Ryser, E.T., and Smith, D.M. (2001). Thermal inactivation of Salmonella spp., Salmonella typhimurium DT104, and Escherichia coli O157:H7 in ground beef. J. Food Sci., 66, 1164-1168.

Takhar, P.S., Head, K.L., Hendrix, K.M., and Smith, D.M. (2009). Predictive modeling of Salmonella species inactivation in ground pork and turkey during cooking. Int. J. Food Eng., 5, 2. DOI: https://doi.org/10.2202/1556-3758.1642.

Tuntivanich, V., Orta-Ramirez, A., Marks, B.P., Ryser, E.T., and Booren, A.M. (2008). Thermal inactivation of Salmonella in whole muscle and ground turkey breast. J. Food Prot., 71, 2548-2551.

[USDA] United States Department of Agriculture, Food Safety and Inspection Service (1996). Nationwide raw ground turkey microbiological survey. Retrieved from: https:/www.fsis.usda.gov/wps/wcm/connect/468690cc-7b6d-4a44$\mathrm{a}^{5} \mathrm{~d} \mathrm{~d}_{7} 619 \mathrm{f35b1f5facfd/rwgrturk.pdf?MOD=AJPERES}$.

[USDA] United States Department of Agriculture, Food Safety and Inspection Service (2012). Ground beef and food safety. Retrieved from: https://www.fsis.usda.gov/shared/PDF/Ground_Beef_and_Food_Safety.pdf? redirecthttp=true.

[USDA] United States Department of Agriculture, Food Safety and Inspection Service (2013). Proper thermometer placement. Retrieved from: https://www.fsis.usda.gov/wps/portal/fsis/topics/food-safety-education/teach-others/ fsiseducational-campaigns/thermy/proper-thermometerplacement/ct_index\#: :text=When\%20cooking\%20whole $\% 20$ poultry\%2C\%20the, thigh\%20(avoiding\%20the\%20bone).

[USDA] United States Department of Agriculture, Food Safety and Inspection Service (2018). Jennie-O Turkey Store Sales, Inc. recalls raw ground turkey products due to 32 possible Salmonella Reading contamination. Retrieved from: https://www.fsis.usda.gov/wps/portal/fsis/topics/recalls-and-public-health-alerts/recall 7634 case-archive/ archive/2018/recall-124-2018-release.

[USDA] United States Department of Agriculture, Food Safety and Inspection Service (2019). Butterball LLC recalls turkey products due to possible Salmonella Schwarzengrund contamination. Retrieved from: https://www.fsis.usda.gov/recallsalerts/butterball-llc-recalls-turkey-products-due-possible-salmonellaschwarzengrund. 
[USDA] United States Department of Agriculture, Food Safety and Inspection Service (2020). Safe minimum internal temperature chart. Retrieved from: https://www.fsis.usda.gov/wps/portal/fsis/topics/food-safety- education/getanswers/food 7642 safety-fact-sheets/safe-food-handling/safe-minimum-internal-temperature-chart/ct_index.

[USDA] United States Department of Agriculture, Food Safety and Inspection Service (2021). FSIS issues public health alert for raw ground turkey products linked to Salmonella hadar illness. Retrieved from: https://www.fsis.usda.gov/ recalls-alerts/fsis $\rceil 646$ issues-public-health-alert-raw-ground-turkey-products-linked-salmonella-hadar.

Veeramuthu, G.J., Price, J.F., Davis, C.E., Booren, A.M., and Smith, D.M. (1998).Thermal inactivation of Escherichia coli O157:H7, Salmonella senftenberg, and enzymes with potential as time-temperature indicators in ground turkey thigh meat. J. Food Prot., 61, 171-175.

White, D.G., Zhao, S., Sudler, R., Ayers, S., Friedman, S., Chen, S., McDermott, P., McDermott, S., Wagner, D., and Meng, J. (2006). The isolation of antibiotic-resistant Salmonella from retail ground meats. N. Engl. J. Med., 345, 11461154.

Wong, M.K., Sampugna, J., and Dickey, L.E. (1993). Moisture, total lipid, fatty acids, and cholesterol in raw ground turkey. J. Agri. Food Chem., 41, 1229-1231.

Cite this article as: Minh Duong, Anna, C.S. Porto-Fett, Bradley A Shoyer, Yangjin Jung, Laura, E. Shane, Manuela Osoria, Elizabeth Henry, Benjamin, J. Chapman and John, B. Luchansky (2021). Thermal Inactivation of Salmonella spp. Within Refrigerated or Frozen Turkey Burgers Following Pan Frying. International Journal of Agricultural Sciences and Technology. 1(4), 1-12. doi: 10.51483/IJAGST.1.4.2021.1-12. 